\title{
Spatial distribution of the sibling species of Anopheles gambiae sensu lato (Diptera: Culicidae) and malaria prevalence in Bayelsa State, Nigeria
}

\author{
Amawulu Ebenezer ${ }^{1,2}$, Aline Edith Mekeu Noutcha ${ }^{1}$, Peter I Agi ${ }^{1}$, Samuel N Okiwelu ${ }^{1 *}$ and Thomas Commander ${ }^{3}$
}

\begin{abstract}
Background: Much of the confusing ecophenotypic plasticity of Anopheles gambiae sensu lato is attributable to the differential biological traits of the sibling species, with their heterogeneous geographical distribution, behavioral dissimilarities and divergent population dynamics. These differences are critical to their roles in malaria transmission. Studies were, therefore, undertaken on the spatial distribution of these species and malaria prevalence rates in Bayelsa State, September, 2008-August 2010.

Methods: Mosquito sampling was in 7 towns/villages in 7 Local Government Areas (LGAs) in 3 eco-vegetational zones: Fresh Water Swamp Forest (FWSF): Sagbama, Yenagoa, Kolokuma-Opokuma LGAs; Brackish Water Swamp Forest (BWSF): Ogbia, Ekeremor, Southern ljaw LGAs; Mangrove Water Forest (MWF): Nembe LGA. Adults were collected twice quarterly by the Pyrethrum Spray Catch (PSC) technique. Anopheles was separated morphologically and the sibling species PCR- identified. Simultaneously, malaria prevalence rates were calculated from data obtained by the examination of blood smears from consenting individuals at hospitals/clinics.

Results: An. gambiae s.S. was dominant across the 3-eco-vegetational zones. Spatial distribution analyses by cell count and nearest neighbor techniques indicated a tendency to clustering of species. An. gambiae s.s. and An. arabiensis clustered in Ekeremor LGA while these 2 species and An. melas aggregated in Nembe. The gonotrophic (physiological) status examination revealed that 34.3, 23.5, 23.1 and 18.4\% of the population were fed, unfed, gravid and half gravid respectively. The highest malaria prevalence rates were obtained at Kolokuma-Opokuma and Nembe LGAs. Variation in prevalence rates among LGAs was significant $(t=5.976, \mathrm{df}=6, \mathrm{p}$-value $=0.002, p<0.05)$. The highest prevalence rate was in the age group, 30-39 yrs, while the lowest prevalence was in the 0-9 yrs group.

Conclusion: High malaria prevalence rates were associated with An. gambiae s.s. either in allopatry or sympatry across eco-vegetational zones. In areas where the sibling species clustered, they probably formed nidi for transmission. Socio-economic conditions might have contributed to reduced prevalence in Yenagoa, State Capital.
\end{abstract}

Keywords: An. gambiae s.I, Sibling species, Malaria prevalence, GIS, Distribution, Bayelsa- State

\section{Background}

Much of the confusing eco-phenotypic plasticity of $A n$. gambiae s.l. is the differential biological traits of the sibling species, their heterogeneous geographical distributions, behavioral dissimilarities and divergent population dynamics [1]. These differences are critical to the transmission of malaria in different zones of Nigeria [2-5].

\footnotetext{
*Correspondence: okiwelu2003@yahoo.com

'Department of Animal and Environmental Biology, University of Port-Harcourt, Port-Harcourt, Nigeria

Full list of author information is available at the end of the article
}

Human malaria is caused by Plasmodium parasites and transmitted by female Anopheles mosquitoes. In Africa, the most efficient vectors are the Anopheles gambiae complex and Anopheles funestus group. An. gambiae is a complex of seven sibling species varying in their vectorial ability and ecological niche [6,7]. The sibling species are: the Freshwater An. gambiae s.s., An. arabiensis, An. quadrianulatus $A$, An. quadrianulatus $B$; the salt waterbreeding An. melas and An. merus, and An. bwambae found in hot springs in Uganda. The differences in the biology of the sibling species of An. gambiae s.l. have

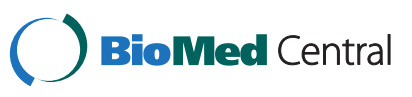


highlighted the need for mapping their spatial distribution and malaria prevalence patterns in order to enhance effective implementation of integrated control approaches [8]. Maps have been produced at continental and subregional scales [9]. The present study is aimed at developing a GIS- based overlay on the spatial patterns of PCR-identified sibling species of An. gambiae complex and Plasmodium falciparum malaria in Bayelsa State, Nigeria.

\section{Methods \\ Study area}

The study was conducted in 7 Local Government Areas (LGAs), Bayelsa State, Nigeria. Bayelsa State is located $\left(5^{\circ} 22^{\prime} \mathrm{E}, 6^{\circ} 45^{\prime} \mathrm{E}\right.$ and $\left.4^{\circ} 15^{\prime} \mathrm{N}, 5^{\circ} 23^{\prime} \mathrm{N}\right)$ in the lower Delta plain formed during the Holocene of the quaternary period by the accumulation of sedimentary deposits [10]. The vegetation comprises three eco-vegetational zones: fresh water swamp forest, brackish water swamp forest and mangrove coastal water forest. The topography of study area is characterized by a maze of creeks and swamps criss-crossing the low-lying plain. The study LGAs were Yenagoa ( $4^{\circ} 53^{\prime} \mathrm{N}$ and $\left.5^{\circ} 17^{\prime} \mathrm{E}\right)$, Sagbama (50.' $\mathrm{N}$ and $\left.6^{\circ} 14^{\prime} \mathrm{E}\right)$, Kolokuma-Opokuma $\left(5^{\circ} 09^{\prime} \mathrm{N}\right.$ and $\left.6^{\circ} 14^{\prime} \mathrm{E}\right)$ in the fresh water swamp forest; Ogbia $\left(4^{\circ} 53^{\prime} \mathrm{N}, 6^{\circ} 22^{\prime} \mathrm{E}\right)$, Southern Ijaw $\left(4^{\circ} 07^{\prime} \mathrm{N}, 6^{\circ} 08^{\prime} \mathrm{E}\right)$ Ekeremor $\left(5^{\circ} 02^{\prime} \mathrm{N}\right.$ and $\left.5^{\circ} 48^{\prime} \mathrm{E}\right)$ in the brackish water swamp forest and Nembe $\left(4^{\circ} 27^{\prime} \mathrm{N}\right.$ and $\left.6^{\circ} 26^{\prime} \mathrm{E}\right)$ in the mangrove coastal water forest. All LGAs were rural, with the exception of semi-urban Yenagoa, the State capital. Many houses had traditional architectural design with mud walls and thatched roofs while few were built with blocks and roofed with corrugated iron sheets. The major occupations of the people were fishing, farming and petty trading.

\section{Ethical consideration}

Before the commencement of the study, consent was obtained from the Ministry of Health, Bayelsa State, through the Primary Health Care (PHC) department, the village and household heads.

\section{Sample size}

Sampling of the study population involved successive selection of new participants who presented at the OutPatient Department of the 7 selected General Hospitals/ Clinics (Okolobiri, Olobiri, Sagbama, Amasoma, Ekeremor, and Kaiama) in each LGA until a sample size as described in Daniel [11] was obtained. These were individuals of all ages who had lived for at least 6 months and planned to stay for a further 6 months in the study areas. A total of 6321 individuals presented at the hospital, September, 2008- August, 2010.

\section{Blood sample collection}

EDTA bottles were labeled following entry into the routine register with data on sex, occupation, and location of participants. A 2 ml-volume of intravenous blood was collected from each individual and transferred to a labeled EDTA bottle. Grease-free slides were labeled using patients' details from the EDTA bottles. An aliquot of the blood was measured with a $1 \mathrm{ml}$-micropipette and dropped on a labeled slide to prepare thick and thin blood films following WHO standard procedures [12]. Preparations were air-dried and fixed with methanol for 30 seconds then stained with $4 \%$ Giemsa in phosphate buffer (7.2) for 30 minutes. Microscopy was used to examine the smears for the presence of malaria parasites under X1000 objective (Olympus, Japan) in oil immersion. Preliminary examination was carried out at the hospital where the blood was collected. The presence of malaria parasites in sexual and asexual stages was considered a positive diagnosis. The second and third examinations were at The Parasitology Research Laboratory, Department of Animal and Environmental Biology, University of Port Harcourt for quality assurance. Slides were reported as negative for malaria parasites after examining at least 50 fields and no parasites were detected. Prevalence rates were calculated.

\section{Mosquito collection}

Collection of mosquitoes was undertaken in 7 villages/ towns in the 7 LGAs. Their co-ordinates were obtained by geographic positioning system (GPS). The villages were randomly selected based on accessibility and availability of supporting staff. Selection of houses was based on their similarity in architectural designs. Six houses were used in each town/ village; these houses were utilized throughout the study. There were 1-2 rooms in each house.

Adult mosquitoes were collected by the Pyrethrum Spray Catch (PSC) method [13]), 0600-0730 hrs twice in each quarter, September, 2008- August, 2010. Selected rooms had at least one person sleeping overnight. Prior to spraying, the floors were covered with clean white sheets, outlets were closed and pyrethroid sprayed; the sheets were removed 15 min post-spray. Knocked down mosquitoes were picked up with pointed tip forceps and placed in labeled plastic cups. The gonotrophic (physiological)

Table 1 Summary of nearest neighbour analysis

\begin{tabular}{ccccc}
\hline Variables & $\begin{array}{c}\text { Mean } \\
\text { distance } \\
\text { (D) in } \mathbf{~ k m}\end{array}$ & $\begin{array}{c}\text { Number of } \\
\text { points (N) }\end{array}$ & $\begin{array}{c}\text { Total } \\
\text { distance }\end{array}$ & $\begin{array}{c}\text { Nearest } \\
\text { neighbour }\end{array}$ \\
\hline $\begin{array}{c}\text { Anopheles gambiae } \\
\text { sibling species }\end{array}$ & 8.415 & 32 & 269.28 & $0.57^{*}$ \\
\hline
\end{tabular}

* $\mathrm{Rn}$ is near cluster. 


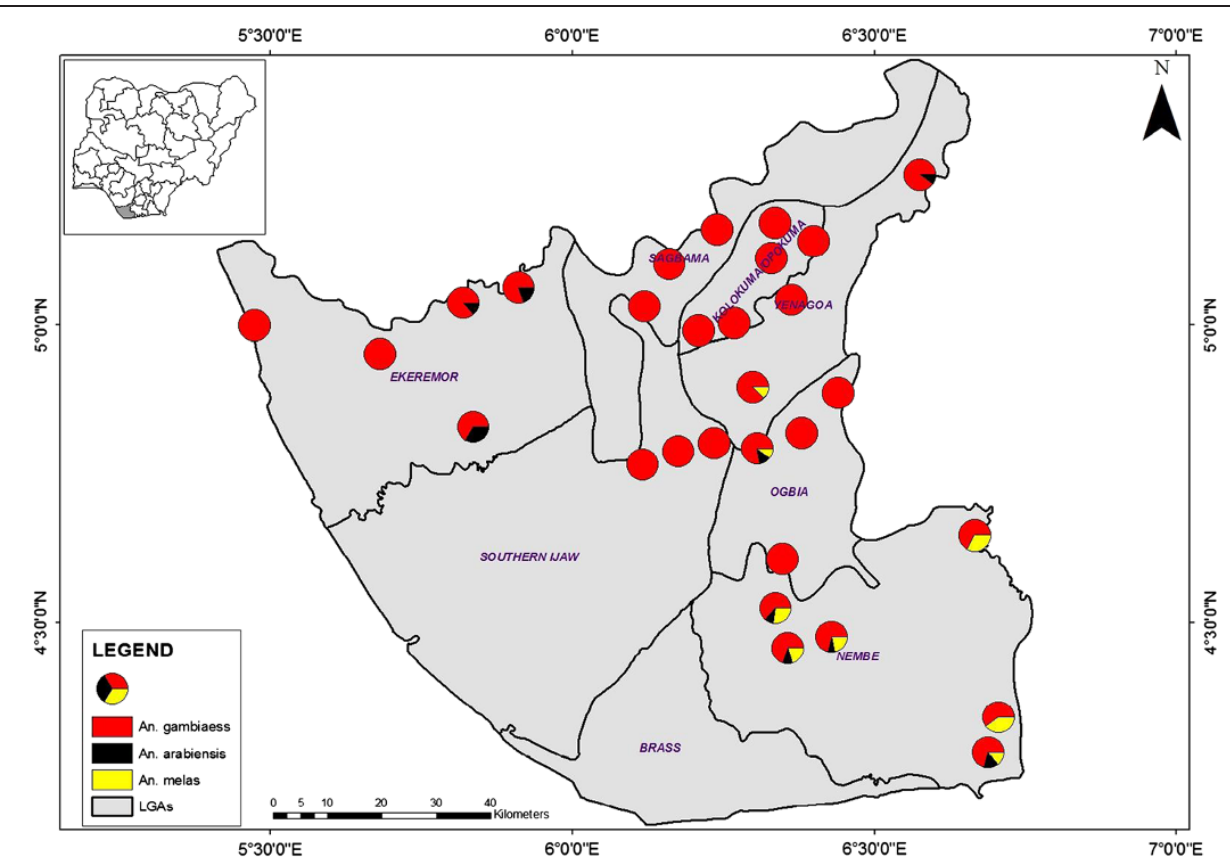

Figure 1 Spatial distribution of Anopheles gambiae sibling species across LGAs.

stages were determined as per WHO [14] and Noutcha and Anumudu [4]. Based on abdominal conditions, they were grouped as: unfed, fed, half gravid and gravid. Unfed females had a dark and flattened abdomen; fed had a dark red abdomen with blood occupying most of the abdomen; in half gravid, blood occupied only 3-4 segments of the ventral surface and 6-7 segments of the dorsal surface of the abdomen; in gravid females, most blood was digested and the abdomen was whitish and distended. Subsequently, the mosquitoes were taken to the laboratory for morphological identification using keys by Gilles and de Meillon [15]. An. gambiae s.l. adults were preserved dried in Eppendorf tubes containing desiccated silica gel for molecular characterization.

\section{PCR- Identification of the members of an. gambiae complex}

Extraction method had been extensively discussed [16].

\section{Map processes}

A scanned administrative map (1:500.000) of the State was geo-referenced and digitized using Arc View GIS software (version 3.29 ESRI CA, USA) [17,18]. Separate layers were created for the Plasmodium falciparum malaria prevalence rates and PCR-identified An. gambiae complex from each site. Spatial maps were displayed and classified using a specific identifier of Arc View Spatial Extension [13].

\section{Spatial analyses}

The cell count and K-nearest neighbor analyses in Dave and Uriel [19] were adapted to describe the spatial distribution patterns. The, Mean Variance Ratio (MVA) and near-neighbor $(\mathrm{Rn})$ values were calculated. When MVA or $\mathrm{Rn}$ was $<1$, the spatial pattern is described as clustered (aggregated); when they are equal to 1 , the spatial pattern is random and when it is $>1$, the spatial pattern is even (uniform).

\section{Results}

Five culicid species (Culex quinquefasciatus (46.5\%), Anopheles gambiae s.l. (31.3\%), Aedes aegypti (13.8\%), Anopheles funestus (6.1\%) Anopheles nili (2.3\%) were identified during the survey. Differences in species abundance were significant $(\mathrm{F}=21.64 ; \mathrm{df}=4, \mathrm{p}$-value $=0.00, \mathrm{p}<0.05)$.

\section{Species composition of An. gambiae complex}

Three species (Anopheles gambiae s.s., An. arabiensis, An. melas) were identified. An. gambiae s.s. was dominant

Table 2 Malaria prevalence rates in study LGAs

\begin{tabular}{ccccc}
\hline $\begin{array}{c}\text { Eco- vegetational } \\
\text { zones }\end{array}$ & LGAs & $\begin{array}{c}\text { No. of humans } \\
\text { examined }\end{array}$ & $\begin{array}{c}\text { No. } \\
\text { positive }\end{array}$ & $\begin{array}{c}\% \\
\text { positive }\end{array}$ \\
\hline Fresh water & Yenagoa & 1980 & 245 & 12.4 \\
& Sagbama & 575 & 159 & 27.7 \\
& Kolokuma & 602 & 409 & 69.9 \\
Brackish water & Ogbia & 967 & 215 & 22.2 \\
& Southern & 600 & 169 & 28.2 \\
& ljaw & & & \\
& Ekeremor & 988 & 177 & 18.5 \\
Mangrove forest & Nembe & 609 & 322 & 52.9 \\
\cline { 3 - 4 } Total & & $\mathbf{6 3 2 1}$ & $\mathbf{1 6 9 6}$ & $\mathbf{3 3 . 0}$ \\
\hline
\end{tabular}




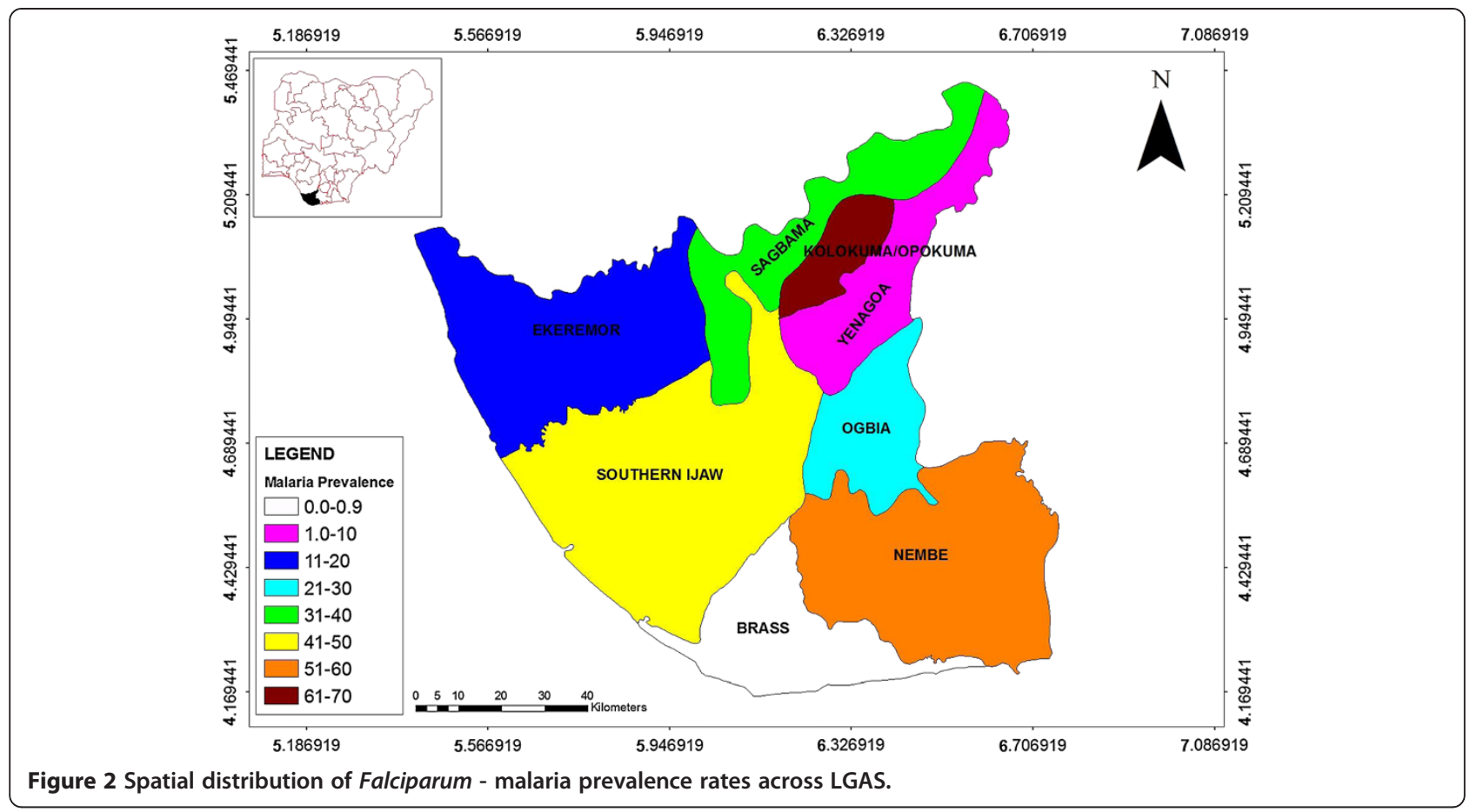

across eco-vegetational zones. Detailed data appear in Ebenezer et al. [16].

\section{Spatial distribution of An. gambiae complex and $P$. falciparum}

The spatial patterns of $A n$. gambiae sibling species across the study locations showed a tendency to clustering or aggregation $(\mathrm{MVA}=0.57, \mathrm{Rn}=0.57) \quad($ Table 1$)$. An. gambiae s.s. and An. arabiensis were sympatric in Ekeremor, while the 3 species (including An. melas) were sympatric in Nembe (Figure 1). The gonotrophic (physiological) status examination revealed that 34.3, 23.5, 23.1 and $18.4 \%$ of the population were fed, unfed, gravid and half gravid respectively. The highest malaria prevalence rates were obtained at Kolokuma-Opokuma and Nembe LGAs and least in Yenagoa LGA (Table 2). Variation in prevalence rates among the LGAs was significant $(\mathrm{t}=$ 5.976, $\mathrm{df}=6, \mathrm{p}$-value $=0.002, \mathrm{p}<0.05)$. Classifications of the $P$. falciparum-malaria endemicity were: Hypoendemic $(\mathrm{PR} \leq 10<40 \%)$ in Yenagoa, Ekeremor Sagbama and Ogbia LGAs; Mesoendemic (PR $\geq 40 \% \leq 50 \%$ ) in Southern Ijaw LGA and Hyperendemic (PR $>50 \%)$ in Nembe and Kolokuma-Opokuma LGAs (Figure 2). The highest prevalence rate was recorded in the 30-39 yrs age group, and the lowest prevalence was recorded in the 0-9 yrs group (Table 3).

\section{Discussion}

The clustered spatial patterns among the An gambiae sibling species were similar to results obtained by Sogoba et al. [20] and probably reflected variation in the favorability of the environment [21]. Sympatric occurrence of the An. gambiae complex had been documented [5]. These clusters may serve as nidi of transmission; they may also serve as refugia, where pathogens, vectors and hosts persist during unfavorable periods [22]. The Anopheles gambiae s.l. population was virile, with approximately $35 \%$ fed and about $40 \%$ half gravid or gravid.

Breman [23] provided a list of intrinsic and extrinsic determinants of the malaria burden. The intrinsic factors include: host genetic susceptibility and host immunological status. The extrinsic factors are: parasite species, mosquito species and environmental conditions. Environmental conditions are climatic conditions, and availability of breeding sites. The socio-economic component consists of education, social, behavioural, political and

Table 3 Age-specific prevalence rates of malaria infection, 2008-2010

\begin{tabular}{cccc}
\hline Age range (Yrs) & $\begin{array}{c}\text { No of persons } \\
\text { examined }\end{array}$ & No. positive & \% positive \\
\hline $0-9$ & 865 & 100 & 11.6 \\
$10-19$ & 1053 & 296 & 28.1 \\
$20-29$ & 1588 & 264 & 16.6 \\
$30-39$ & 1333 & 646 & 48.5 \\
$40-49$ & 714 & 228 & 31.9 \\
$50-59$ & 469 & 134 & 28.6 \\
$\geq 60$ & 299 & 28 & 9.4 \\
Total & 6321 & 1696 & 27.4 \\
\hline
\end{tabular}


economic status of host populations. Parasite and host populations were apparently not responsible for the variation in malaria prevalence across the State. There were no differences in species of parasites. It was unlikely that genetic susceptibility and immunological status of human hosts varied significantly across the ecovegetational zones and the semi urban/rural divide in the State. Warm temperature, high rainfall and humidity were pervasive across the State; breeding sites were also available because adults were collected throughout the year.

The low malaria prevalence rates in Yenagoa LGA, the State capital and the only semi-urban location in the study area was probably due to the higher living standard (better housing, knowledge of disease, community participation in malaria prevention and control) [24,25]. One of the factors that might have contributed to the high prevalence rates in Nembe LGA, might be attributable to the clusters of the 3 sympatric An. gambiae sibling species that formed nidi for transmission [22]. The high prevalence rates in Kolokuma-Opokuma, where An. gambiae s.s. was abundant and allopatric could be attributed to the high density and vectorial competence of the efficient An. gambiae s.s. as a malaria vector $[1,6,16,20,26]$. This efficiency may also explain the relatively high prevalence rates in Sagbama and in the area of Southern Ijaw LGA, contiguous with Sagbama where An. gambiae S.s. was allopatric. Although the literature indicates that annual deaths from malaria are mainly in infants and young children [27,28]; these results show the highest prevalence rate in the $30-39$ yrs age group. It is apparent that the source and composition of sample populations have a significant impact on the pattern of malaria prevalence rates across age groups.

\section{Conclusion}

High malaria prevalence rates were associated with $A n$. gambiae s.s. either in allopatry or sympatry across ecovegetational zones. In areas where the sibling species clustered, they probably formed nidi for transmission. Socio-economic conditions might have contributed to reduced transmission in Yenagoa, State Capital.

\section{Competing interests}

The authors declare that they have no competing interests.

\section{Authors' contributions}

AE was the doctoral student responsible for the fieldwork and laboratory analyses. MAEN designed the molecular component of the doctoral proposal and supervised the morphological identification of Anopheles gambiae s.l. PIA was the Co-Supervisor of AE's doctoral project. SNO was the Principal Supervisor of AE's doctoral project and corresponding author. TC facilitated field collections at the communities in Bayelsa State. All authors read and approved the final version of the manuscript.

\section{Acknowledgement}

The collaboration of communities at study towns and villages is gratefully acknowledged.

\section{Author details}

${ }^{1}$ Department of Animal and Environmental Biology, University of Port-Harcourt, Port-Harcourt, Nigeria. ${ }^{2}$ Department of Biology, Isaac Jasper Boro College of Education, Bayelsa State, Nigeria. ${ }^{3}$ Department of Biological Sciences, Niger Delta University, Wilberforce Island, Bayelsa State, Nigeria.

Received: 19 July 2013 Accepted: 4 January 2014

Published: 17 January 2014

\section{References}

1. White GB: Anopheles gambiae complex and disease transmission in Africa. Trans R Soc Trop Med Hyg 1974, 68:278-298.

2. Samdi IM, Anyanwu GI, Molta NB, Awolola TS, Oduola AO, Obansa J, Watula IM, Oguche S: Determination of malaria vectorial status of Anopheles mosquitoes of the Sahel, North-Eastern Nigeria. J Life Env Sc 2006, 8(1):442-448

3. Oyewole O, Adejoke C, Oduola AA, Judith BO, Awolola TS: Molecular identification and population dynamics of the major vectors in a rain forest zone of Nigeria. Biokemistri 2005, 17(2):171-178.

4. Noutcha MAE, Anumudu Cl: Entomological indices of Anopheles gambie s.l. at a rural community in Southeast Nigeria. J Vector Borne Dis 2009, 45:43-51.

5. Oduola AO, Otubanjo JH, Olojede JB, Oyewole IO, Awolola TS: Malaria transmission risk indices of three Anopheles species in selected rural communities in Oyo State South-West Nigeria. Int J Trop Med 2012, $7(1): 42-48$.

6. Coetzee M, Craig M, Le Sueur D: Distribution of African malaria mosquitoes belonging to the Anopheles gambiae complex. Parasitol Today 2000, 16:74-77.

7. Coluzzi M, Sabatini A, della Torre A, Di Deco MA, Petrarca V: A polythene chromosome analysis of Anopheles gambiae complex. Science 2002, 298:1415-1418.

8. Touré YT, Oduola AM, Morel CM: The Anopheles gambiae genome. Next steps for malaria vector control. Trends in Parasitol 2004, 439:576-579.

9. Levine RS, Peterson AT, Benedict MO: Geographic and ecological distributions of the Anopheles gambiae complex predicted using a genetic algorithm. Am J Trop Med Hyg 2004, 70:105-109.

10. Alagoa EJ: The land and people of Bayelsa State Central Niger Delta. Port Harcourt, Nigeria: Onyema Research Publications; 1999:167.

11. Daniel WW: Practical issues in calculating the sample size for prevalence studies. In Naing WT and Rusli BN. Medical Statistics 2006, 1:9-10.

12. World Health Organisation: World Report of Tropical Diseases. Geneva: World Health Organisation feature. No 139; 1990.

13. World Health Organization: Vector control for malaria and other mosquitoborne diseases. Geneva, Switzerland: WHO Technical Report series 857, World Health Organization; 1995.

14. World Health Organization: GIS and Public Health Mapping. World Health Organization; 2003. www.who.int. Accessed 19 July, 2013.

15. Gillies MT, De-Meillon B: Anohelinae of Africa south of the Sahara (Ethiopian Zoographical Region) publ. South Afr Inst Med Res 1968, 54:37-41.

16. Ebenezer A, Okiwelu SN, Agi PI, Noutcha MAE, Awolola TS, Oduola AO: Species composition of the Anopheles gambiae complex across ecovegetational zones in Bayelsa State, Niger Delta region, Nigeria. J Vector Borne Dis 2012, 49:164-167.

17. Martin C, Curtis B, Fraser C, Sharp B: The use of a GIS-based malaria research and control in South Africa. Health and Place 2002, 8:221-236.

18. Ekpo UF, Mafiana CF, Adeofun CO, Solarin ARJ, Idowu AB: Geographic Information System (GIS) and risk maps of urinary schistosomiasis in Ogun State, Nigeria. Nig J Parasitol 1998, 28(1):42-49.

19. Dave DE, Uriel K: Spatial and temporal pattern of imported malaria cases and local transmission in Trinidad. Am J Trop Med Hyg 1999, 61(1):513-517

20. Sogboba N, Vounatson P, Bagayoko MM, Doumbia S, Dolo G, Gosonu G, Traoré SF, Touré YT, Smith T: The spatial distribution of Anopheles gambiae stricto sensu and An. arabiensis (Diptera. Culicidae) in Mali. Geospat Health 2007, 2:43-22.

21. Mboera LEG, Seukoro KP, Mayala BK, Rumisha SF, Rivegoshora RT, Mlozi MRS, Shaya E: Spato-temporal variation in malaria transmission intensity in five agro- ecosystem in Mvomero district, Tanzania. Geospat Health 2010, 4(2):167-178 
22. Reisen WK: Landscape epidemiology of vector-borne diseases. Ann Rev Entomol 2010, 55:461-483.

23. Breman JG: The ears of the hippopotamus: manifestations, determinants and estimates of the malaria burden. Am J Trop Med Hyg 2001, 64(1):1-11.

24. Gamage-Mendis AC, Carter R, Mendis C, De Zoysa AP, Harath PR, Mendis KN: Clustering of malaria infections within an endemic population: risk of malaria associated with type of house construction. Am J Trop Med Hyg 1991, 45:77-85.

25. Yazuome Y, Hoshen M, Louis V, Seraphin S, Traore I, Saurerborn R: Housing conditions and Plasmodium falciparum infections: protective effect of iron-sheet roofed houses. Malar J 2006, 5:8-14.

26. Gempeli A, Vounatson P, Sogoba N, Smith T: Malaria mapping using transmission models, application to survey data from Mali. Am J Epidemiol 2006, 163:289-297.

27. Cattani J, Davison D, Engers H: Malaria in tropical disease research: Progress. 1991-1992. Pp 15-27. Geneva: WHO; 1993:134.

28. Collins FH, Paskewitz SM: Malaria: current and future prospects for control. Ann Rev Entomol 1995, 40:295-219.

doi:10.1186/1756-3305-7-32

Cite this article as: Ebenezer et al.: Spatial distribution of the sibling species of Anopheles gambiae sensu lato (Diptera: Culicidae) and malaria prevalence in Bayelsa State, Nigeria. Parasites \& Vectors 2014 7:32.

\section{Submit your next manuscript to BioMed Central and take full advantage of:}

- Convenient online submission

- Thorough peer review

- No space constraints or color figure charges

- Immediate publication on acceptance

- Inclusion in PubMed, CAS, Scopus and Google Scholar

- Research which is freely available for redistribution 